\title{
External Morphological Characteristics for Periods during Pecan Microspore and Pollen Differentiation
}

\author{
I.E. Yates \\ Russell Research Center, Agricultural Research Service, U.S. Department of Agriculture, Athens, \\ GA 30613 \\ Darrell Sparks \\ Department of Horticulture, University of Georgia, Athens, GA 30602 \\ Additional index words. Carya illinoensis, staminate flower, meiosis, cytology, cytochemistry, electron microscopy
}

\begin{abstract}
Catkin external morphological characteristics of a protogynous ('Stuart') and a protandrous ('Desirable') cultivar of pecan [Carya illinoensis (Wangenh.) C. Koch] were related temporally to the differentiation of microspore and pollen grains. Reproductive cell development was divided into seven periods based on evaluations of number, location, and intensity of staining of the nucleus and/or nucleolus; and vacuolization and staining intensity of the cytoplasm. Catkins with anthers and bracteoles enclosed by bracts did not have reproductive cells that were matured to free microspore. Free microspore developed only after bracteoles became externally visible. The Period 1 nucleus was at the periphery of the cell and a large central vacuole was present; at Period 2, the nucleus was at the center and vacuolation had been reduced. As the angle between the bract and catkin rachis increased to $45^{\circ}$, vacnolation was reduced as the nucleus enlarged and moved to a central location in the microspore (Periods 3 and 4). The majority of the pollen grains were binucleate, and the generative nucleus became elliptical (Periods 5 and 6 ) by the time anthers became externally visible. Acetocarmine staining intensity of cellular components masked the presence of the generative nucleus (Period 7) just before anther dehiscence. Staining reaction for protein was positive from Period 1; starch from Period 3; lipids and polyphenols from Period 5. The mature pollen grain was abundant in stored reserves of starch and lipids and had a wall with a thicker exine than intine as demonstrated by acetolysis.
\end{abstract}

Pollen is important for fundamental and applied aspects of pecan nut production. The majority of studies on pecan pollen development have focused on topics related to the anatomy of the staminate flower from initiation to budbreak (Haulik, 1985; Haulik and Holtzhausen, 1988; Maximos et al., 1984; Wetzstein and Sparks, 1984; Woodroof, 1930), the varying periods of pollen release among cultivars (Sparks, 1987), carbon translocation (Davis and Sparks, 1971), and viability of stored pollen (Wetzstein and Sparks, 1985; Yates and Sparks, 1989, 1990). Although Woodroof (1930) illustrated meiosis in the microspore mother cell with camera lucida drawings, the developmental events associated with microspore and pollen maturation have not been analyzed. Reproductive cell development from the tetrad period until pollen maturation has been categorized into eight developmental periods for grasses (Knox, 1984) and 12 developmental periods for Lilium (Willemse and Reznickova, 1980) based on changes in cellular composition.

Identifying periods of pecan microspore and pollen differentiation is important for establishing protocols for biochemical or in vitro studies. Selection of donor plants in the appropriate state of development during pollen maturation is a prerequisite for initiating anther cultures that produce haploid plants. Proper assessment of maturation in the reproductive cell is imperative for experimental manipulation because the most responsive anther stage for haploid plant initiation varies among plant species (Sunderland and Dunwell, 1977).

\footnotetext{
Received for publication 25 Jan. 1991. The assistance of Donnie Maxey and Joyce Lambert in the preparation of photomicrographs is gratefully acknowledged. Trade names are used in this publication to provide specific information. Mention of a trade name does not constitute a guarantee or warranty of the product or an endorsement by the USDA over other products not mentioned. The cost of publishing this paper was defrayed in part by the payment of page charges. Under postal regulations, this paper therefore must be hereby marked advertisement solely to indicate this fact.
}

Previous analyses demonstrated that a single marker, expansion of the floret from the main floral axis, could be used to classify three stages in pecan catkin development - appressed, partially appressed, and fully expanded (Cope and Yates, 1987; Yates et al., 1986) Reproductive cells were not differentiated in appressed florets, microspore were associated with partially appressed florets and pollen grains with fully expanded florets. In a preceding paper (Yates and Sparks, 1991), we categorized catkin development into five stages using a combination of markers. The objectives of the current study were to define the periods of development in pecan pollen and determine whether the combination of morphological features of catkin development could be used to predict precise periods of microspore and pollen grain maturation.

\section{Materials and Methods}

Plant material. Catkins were collected at $\gg$ 10:00 AM from four trees each of 'Desirable' and 'Stuart' growing at the Univ. of Georgia Horticulture Farm, Watkinsville, from the time the staminate inflorescence was fully extended out of the bud scales until anther dihiscence. Catkin stage was classified using previously described markers of external morphological characteristics (Yates and Sparks, 1992). At least 20 catkins were harvested for each stage on at least two collection dates with the exception of only one collection for the most mature catkins and one collection of the youngest 'Desirable' catkins.

Cytology and microscopy. Catkins were harvested, fixed, and stored for cytological studies as described by Yates and Sparks (1992). Florets were removed midway of the rachis length and the anthers dissected. Twenty catkins from one collection date were analyzed and scored for the period (Knox, 1984) of microspore and pollen grain development for 'Desirable' and 'Stuart'. Additional catkins collected were analyzed to verify that reproductive cells were in the same period of development as the 
scoring samples. The anthers were placed in a drop of stain, teased apart with forceps, and examined with a Leitz Dialux (LEICA, Wetzlar, Germany) microscope under bright field or differential interference constrast (DIC) optics, as appropriate. Cytological stains used were acetocarmine for nuclear structure (Belling, 1926), potassium iodide for starch (Johansen, 1940), ferric chloride for polyphenols, Sudan IV for lipids (Pearse, 1961), and Coomassie brilliant blue for proteins (Fisher, 1968).

Samples prepared for transmission electron microscopy (TEM) and light microscopy (LM) were fixed overnight at $4 \mathrm{C}$ with $4 \%$ glutaraldehyde and then $1 \mathrm{~h}$ in an ice bath with $1 \% 0 \mathrm{~s}_{4}$ buffered with 0.085 M sodium cacodylate, stained with $1 \%$ uranyl acetate for $1 \mathrm{~h}$ in an ice bath, dehydrated in an ethanol series, and embedded in resin (Spurr, 1969). Sections for LM were stained with a mixture of $1 \%$ Azure II and $1 \%$ sodium borate (1:1). Ultrathin silver sections were cut by means of a Sorvall MT 5000 ultramicrotome (RMC, Tuson, Ariz.) and studied in a Joel Jem-100 CX II TEM (JEOL, USA, Peabody, Maine).

Acetolysis. The stratification of the mature pecan pollen wall was assessed by acetolysis of pollen grains using a modification of a procedure described by Skvarla and Rowley (1970). Pollen grains were placed in a freshly prepared solution of acetic anhydride and sulfuric acid (1:9) and heated to $100 \mathrm{C}$ in a heating block. Samples were removed after 5 and 10 rein, and every 10 min thererafter, and examined by LM for degradation of cellular components. After $1 \mathrm{~h}$ of acetolysis, the pollen grains were washed three times with water and prepared for TEM.

\section{Results}

Microsporogenesis. Newly formed microspore mother cells (MMC) in pecan were multisided structures (Fig. 1A). The nucleus was large and the cytoplasm and nucleoplasm stained more faintly with acetocarmine than the nucleolus. A callose loculus surrounded the MMC before the initiation of meiosis. A MMC forced out of the loculus remained spherical (Fig. 1B). The configuration of the loculus was rounded on the interior and irregular to the exterior.

Projecting striated portions of loculi were evident throughout Meiosis I (Fig. 2A, B) and II (Fig. 2C). There appeared to be no relationship between the orientation of the plane of division and the position of this projection. Division was at right angles (Fig. 2A) to the projection in some MMCS and in others in a more parallel orientation (Fig. 2B) during Meiosis I. Nuclear reorganization at Telophase I occurred without the formation of a distinctive division furrow that became evident near completion of Meiosis II (Fig. 2C). Microspore were oval when arranged in a bilateral tetrad (Fig. 2D). The loculus continued to have a distinctive striated projection up to tetrad formation.

Microspore and pollen grain maturation. The reproductive cell will be referred to as a microspore during the uninucleate periods and as a pollen grain during the binucleate periods. Differentiation of microspore and pollen grains after release of microspore from the tetrad until anther dehiscence was categorized into seven periods based on cytological analyses after acetocarmine staining. Characteristics evaluated were number, location, and comparative density of the nucleus(i) and/or nucleolus(i), extent of vacuolization, and density of the cytoplasm.

Period 1 microspore had a peripherally located nucleus and a large central vacuole occupying the greater portion of the microspore (Fig. 3A). The parietal cytoplasm was denser than that to the interior of the cell. The microspore wall was thickened around the entire periphery and bulged at areas adjacent to the germinal pores.

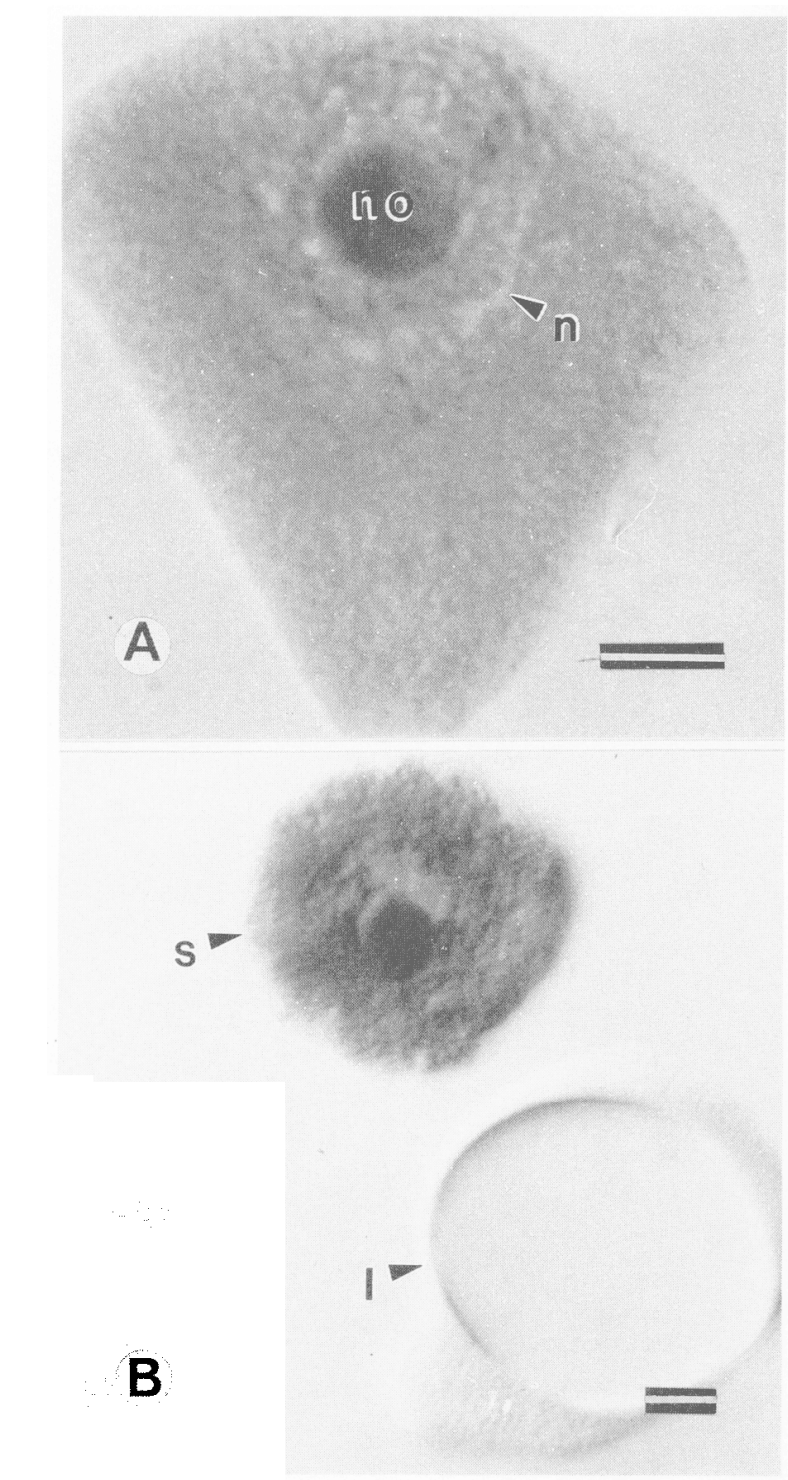

Fig. 1. Light photomicrographs of acetocannine stained microspore mother cells (MMC) prior to the onset of meiosis. (A) Early MMC, $\mathrm{n}=$ nucleus, no $=$ nucleolus. (B) Late MMC released from enclosing callose loculus. $\mathrm{s}=\mathrm{MMC}, 1=$ loculus. Bar $=10 \mu \mathrm{m}$.

The nucleus began to migrate away from the cell periphery and vacuolization was reduced, resulting in a more uniform distribution of the cytoplasm in Period 2 than in Period 1 microspore (Fig. 3B). The extent of vacuolation of Period 3 microspore was greatly reduced and the cytoplasm had an even, grainy appearance (Fig. 3C). During Period 4, the cytoplasm became ridgy (Fig. 3D). The nucleus was much larger and more centrally located, occupying a greater volume of the microspore than in previous stages. The pollen grain at Period 5 was binucleate with spherical generative and vegetative nuclei (Fig. $3 E)$. The generative nucleus in Period 6 pollen grains was elliptical and the cytoplasm was dense and evenly distributed (Fig. $3 \mathrm{~F})$. The most mature pollen grains were designated as Period 7 (Fig. 3G) and stained intensely with acetocarmine, causing the generative nucleus to be obscured and the vegetative nucleus to be barely discernible. A cross section of a fixed pollen grain (Fig. $3 \mathrm{H}$ ) confirmed the density and even distribution of the cytoplasmic contents, and the integrity of both the generative and vegetative nuclei. 

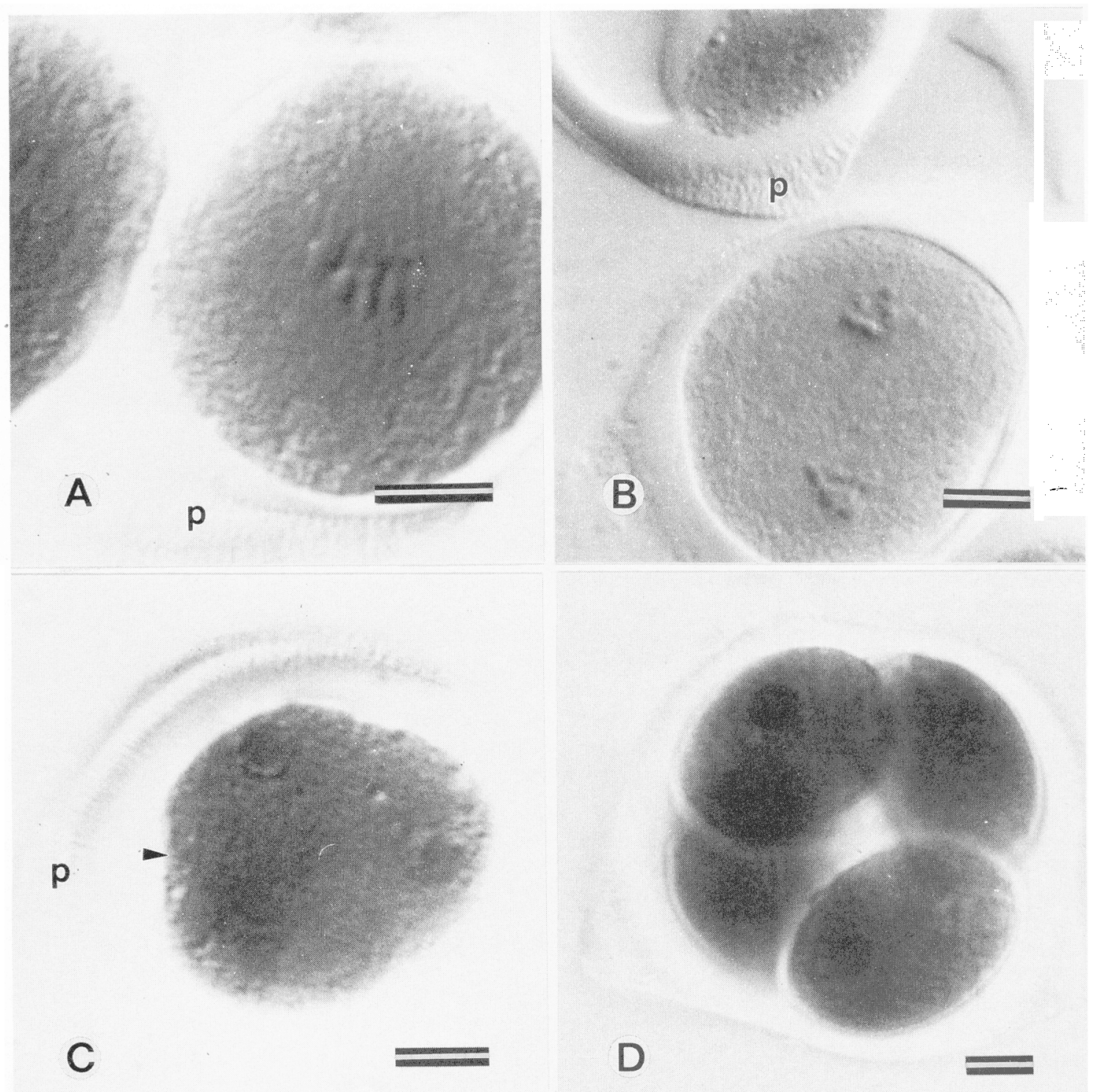

Fig. 2. Light photomicrographs of microsporogenesis in acetocarmine stained pecan microspore mother cells. (A) Metaphase I. (B) Telophase I. (C) Telophase II. Arrow $=$ division furrow. (D) Tetrad. $\mathrm{p}=$ striated projection of loculus. Bar $=10 \mathrm{pm}$.

Period 1 and 2 microspore stained positively for only protein and negatively for starch, fats, and polyphenols (Table 1). A positive starch reaction was obtained once vacuolation was reduced in Period 3 microspore. Lipids and polyphenols were evident by Period 5 when differentiation had progressed to the formation of the binucleate pollen grain.

The dense, evenly distributed cytoplasm in a mature pollen grain as observed with LM was confirmed by TEM (Fig. 4A). Starch was sequestered in amyloplasts, and lipids were sequestered in membrane-bounded bodies. The arrangement of the pecan pollen wall into four zones was conspicuous and will be discussed by numerical identification of each from the exterior toward the interior of the pollen grains. Zones 1 and 3 were electron opaque, with Zone 1 being the thicker of the two and interspersed with microchannels. Zone 2 was electron translucent with particles ranging from electron dense to electron opaque. Zone 4 was the innermost layer and appeared mostly electron translucent, but with a slightly granular appearance. The major portion of the germinal aperture (Fig. 4B) was composed of material contiguous with Zone 4 with a thin exterior coating of material common to Zone 2. Whereas the entire cytoplasmic contents of the pollen grain were degraded after $1 \mathrm{~h}$ of acetolysis, all layers of the pollen wall remained intact with the exception of Zane 4 (Fig. 4C).

Relationship of catkin morphology to reproductive cell development. Analyses by acetocarrnine staining of the cell types present in Stage I catkins demonstrated that reproductive cells had not proceeded to differentiation of free microspore (Table 2 ). Cell types observed in anther smears of Stage I catkins ranged from undifferentiated to tetrads. Even in $15 \%$ of 'Desirable' and $90 \%$ of 'Stuart' catkins of Stage II, reproductive cells were not developed to the free microspore stage. Free microspore were never observed until catkin Stage II in 'Desirable' or 'Stuart'. The majority of anthers from Stage II catkins in 'Desirable' had free microspore of the type designated as either Period 1 (large central vacuole and peripheral nucleus) or Period 2 (reduced vacuolation), while in 'Stuart', most reproductive cells still had no free microspore. Period 3 micro- 

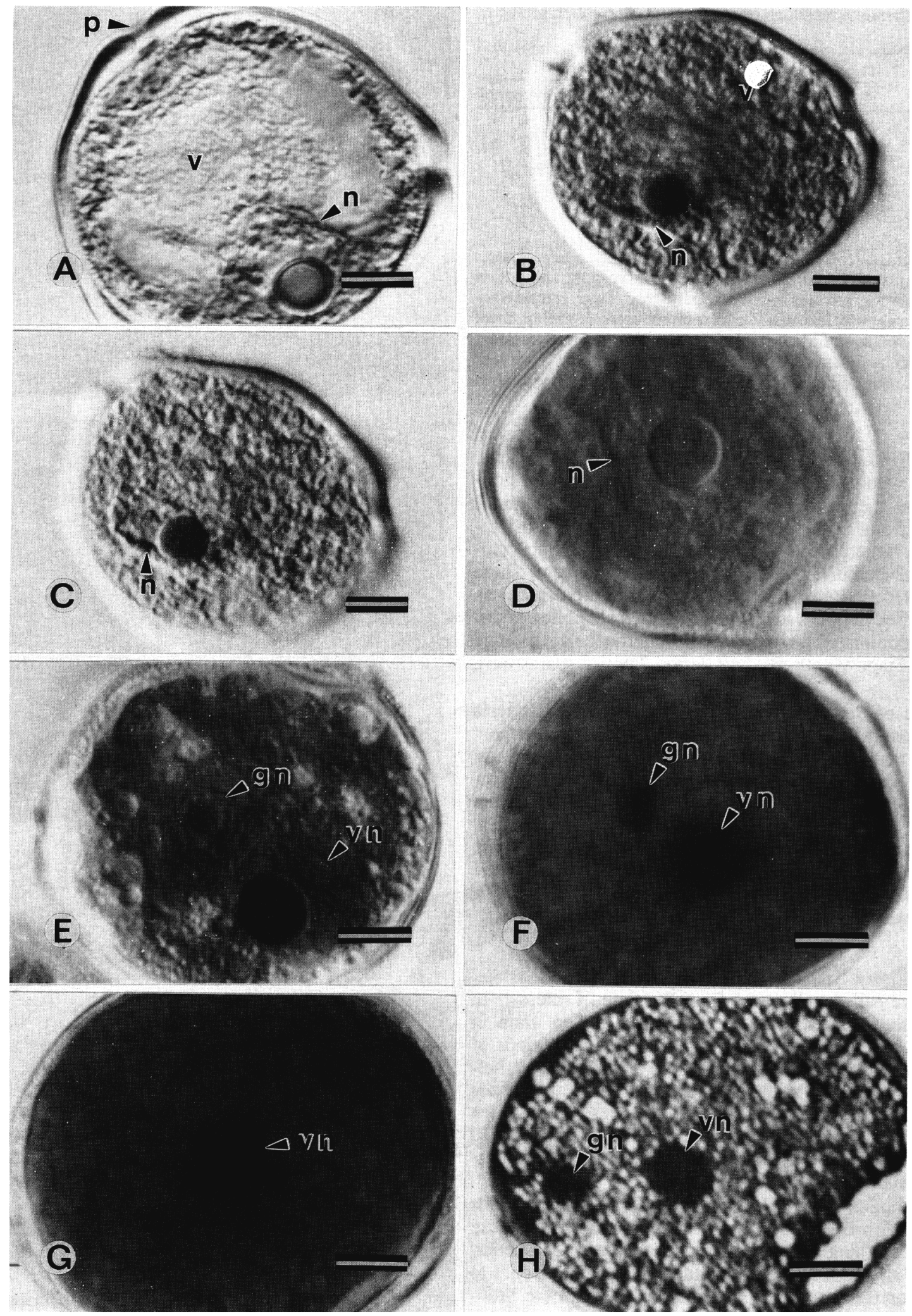

Fig. 3. Light photomicrographs of periods of microspore and pollen grain differentiation. (A) Period 1. (B) Period 2. (C) Period 3. (D) Period 4. (E) Period 5. (F) Period 6. (G) Period 7. (H) Cross section of fixed pollen grain. $\mathrm{p}=$ germinal aperture, $v=$ vacuole; $n=$ nucleus, vn $=$ vegetative nucleus, gn $=$ generative nucleus. Bar $=10 \mu \mathrm{m}$. 
Table 1. Cytochemical reactions of microspores and pollen grains in pecan.

\begin{tabular}{lcccc}
\hline \hline \multirow{2}{*}{$\begin{array}{l}\text { Period of } \\
\text { development }\end{array}$} & \multicolumn{4}{c}{ Cytochemical reaction } \\
\cline { 2 - 5 } & Protein & Starch & Lipid & Polyphenol \\
\hline 1 & + & - & - & - \\
2 & + & - & - & - \\
3 & + & + & - & - \\
4 & + & + & - & - \\
5 & + & + & + & + \\
6 & + & + & + & + \\
7 & + & + & + & + \\
\hline
\end{tabular}

${ }^{2}$ Characteristic(s) distinguishing each period of microspore and pollen grain development: 1, nucleus located at periphery, large central vacuole; 2 , nucleus centrally located, vacuolation reduced; 3 , grainy, even appearance to cytoplasm, little vacuolation; 4, enlargement of nucleus, ridged appearance to cytoplasm; 5, binucleate condition first observed; 6 , generative nucleus becomes elliptical; 7 , staining intensity obscures nucleus.

spores, which had only scant vacuolation, a large central nucleus, and a grainy, even cytoplasm, must represent a rapid developmental. stage as they were observed in only $10 \%$ of Stage III 'Desirable' and not at all in 'Stuart' catkins. Period 4 microspores, with a large central nucleus and densely staining cytoplasm, predominated in Stage III catkins of both cultivars. These cells represented the most mature form of the microspore, as the next identified period was that of the binucleate pollen grain. This form predominated among the reproductive cells of Stage IV catkins. In Stage V catkins, only Period 7 pollen grains were observed.

Comparison of the most distinctive aspects of histogenesis (Yates and Sparks, 1992) and -reproductive cell development demonstrated that free microspores were not present until the tapetum disintegrated (Table 3). Development of binucleate pollen grains coincided with dissolution of the cell layers between the two locules in each anther lobe. 'Stuart' anthers from Stage I and II catkins lagged behind 'Desirable' in histogenesis and reproductive cell development. Reproductive cells characteristic of a developmental period coincided in Stages III, IV, and V catkins of 'Stuart' and 'Desirable', as did anther histogenesis.

\section{Discussion}

Reproductive cell development from the time of microspore release from the callose locule to the mature pollen grain in pecan anthers has been separated into seven distinct periods of differentiation. Most periods of microspore or pollen grain maturation can be associated with catkin stages described in Yates and Sparks (1992). The acquisition of stored reserves and the progression of nuclear and cytoplasmic events can be predicted by evaluating catkins for a combination of external morphological features, such as rachis and anther visibility.

The mature pollen grain in many plant species is rich in lipids and starch (Heslop-Harrison, 1972), as demonstrated for pecan by cytological staining and ultrastructural analyses. The period of maturation at which microspores and pollen grains begin to accumulate stored reserves has been associated with the probability of success in establishing haploid cultures from anthers. Androgenesis was more successful for those plant species in which starch accumulation started after the development of the binucleate pollen grain and less successful for those in which starch accumulated throughout pollen differentiation (Sangwan and Sangwan-Norreel, 1987). Pecan would appear to be an un-
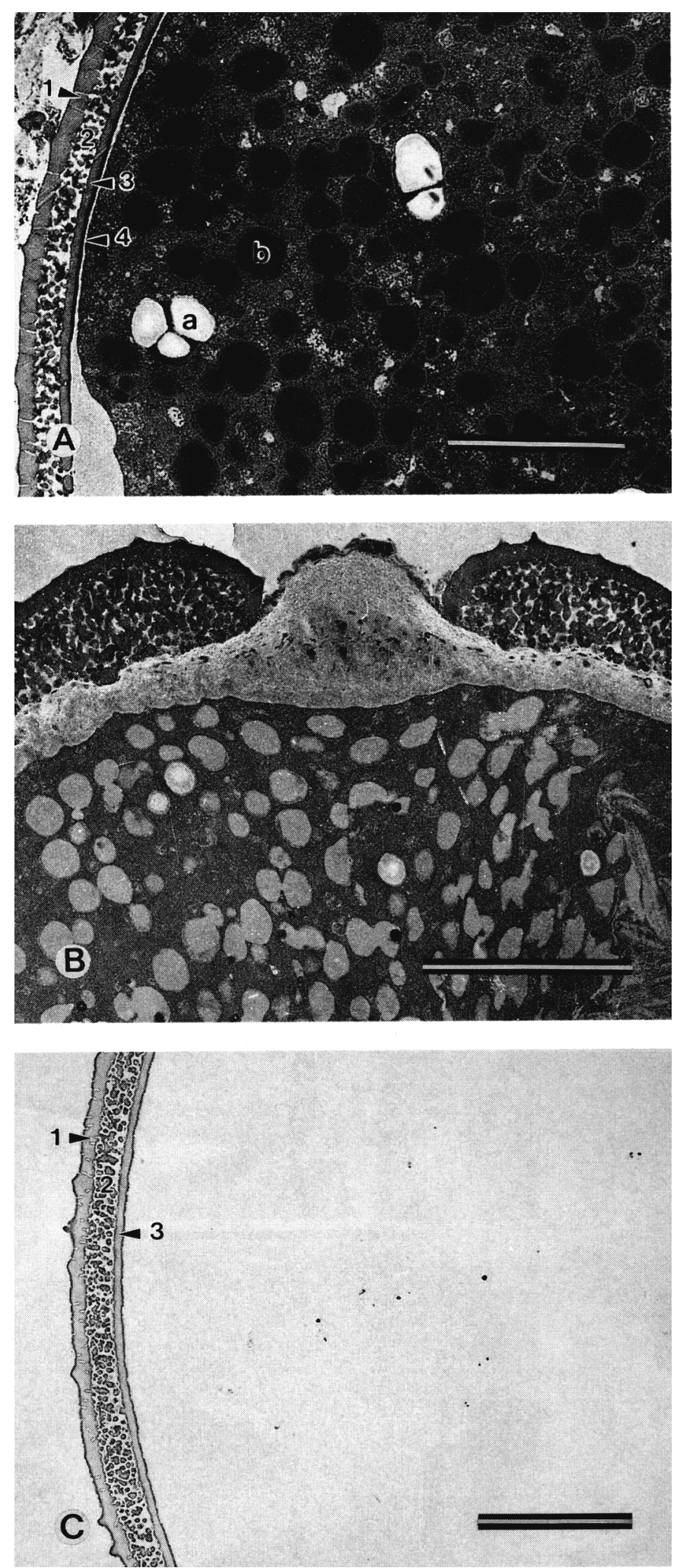

Fig. 4. Transmission electron micrographs of mature pecan pollen grain. (A) Stratification of wall into four zones $(1=$ tectum, $2=$ bacula, $3=$ nexine, $4=$ intine). $\mathrm{a}=$ amyloplast, $\mathrm{b}=$ lipid bodies. (B) Germinal aperture. (C) Residual following 1-h acetolysis $(1=$ tectum, 2 = bacula, $3=$ nexine) . Bar $=0.5 \mu \mathrm{m}$. 
Table 2. Relationship of reproductive cell development to catkin stage.

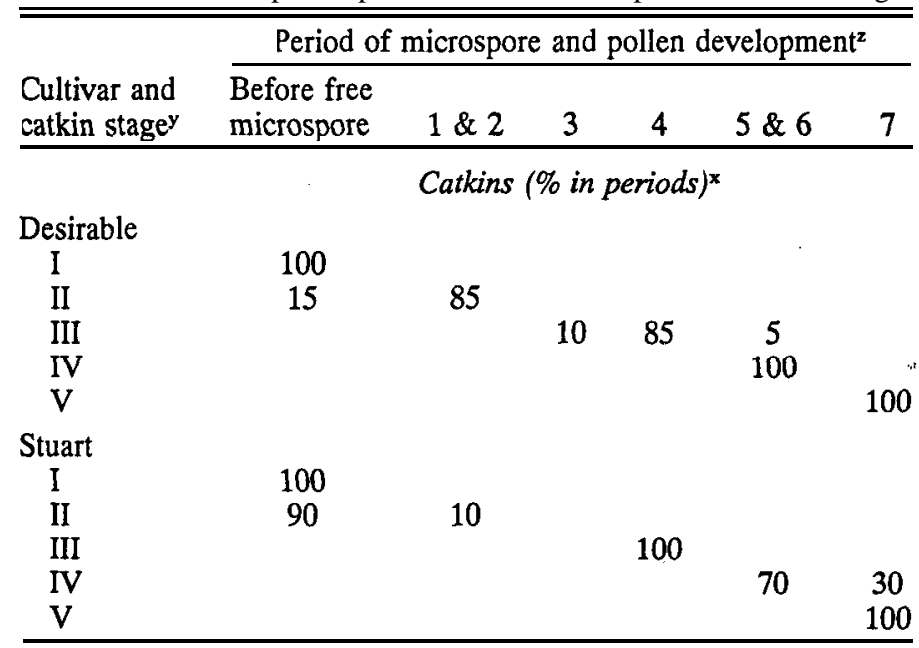

${ }^{2}$ Distinguishing characteristics(s): See Table 1 .

'Distinguishing characteristics(s) (Yates and Sparks, 1992): I, Bracts only externally visible floral part; II, bracts and bracteoles, but not anthers externally visible; III, bracts spread away from main floral axis by $45^{\circ}$; IV, anthers externally visible; $\mathrm{V}$, anthers have yellowish tinge. Based on 20 catkins.

likely candidate for generating haploid plants through anther culture because starch accumulation began before the binucleate condition had developed. A positive reaction for starch occurred for Period 3 microspores, which preceded nuclear enlargement and the first haploid mitosis. Other stored reserves, such as lipids or polyphenols, were not detectable until the binucleate condition was evident (Period 5). Shivanna and Johri (1985) used the concurrent degradation of the tapetum and accumulation of reserve products in the pollen grain as evidence for the tapetum being the source of these materials for the developing pollen grain. Period 5 pollen grains were common to Stage IV catkins in which we observed the absence of the tapetal tissues (Yates and Sparks, 1992).

In the only other cytological examination of pecan pollen (Woodroof, 1930), the mature pecan pollen grain was depicted as uninucleate. The presence of a binucleate condition was alluded to only after formation of a germination tube. We found that pecan pollen had developed a vegetative and generative nucleus while the anthers were green in Stage IV of catkin development. However, the generative nucleus became very obscure in pollen grains just before dehiscence because of the density of other components of the pollen grain. Failure to detect the binucleate condition by Woodroof (1930) may have been due to inadequate sample collection or analytical technique. Ultrastructural examination of nuclear structure in other plants demonstrates that the generative nucleus exists in a cell surrounded by a plasma membrane within the vegetative cell (Knox et al., 1986). Consequently, the modern terminology is generative cell and vegetative cell. However, as we were not able to resolve the plasma membrane by LM, we have used vegetative nucleus and generative nucleus. Controlled self- and cross-pollinations in pecan (Sparks and Madden, 1985) suggested that self-incompatibilities exist in pecan. The type of incompatibility expressed by a plant species has been associated with the nucleate condition of the mature pollen grain (Brewbaker, 1957; Knox et al., 1986). Binucleate pollen generally expressed gametophytic and trinucleate, sporophytic incompatibility. Selfincompatibility in pecan may be of the gametophytic type residing within the pollen genotype as pecan pollen is binucleate.

The nomenclature used to identify the strata of the pollen grain wall has varied with the investigator and will be identified by terminology outlined by Knox (1984). The layers identified as Zones 1 to 3 were exine and Zone 4 was intine based on acetolysis of mature pollen grains. The exine is composed of sporopollenin, which is highly resistant to acetolysis; whereas the polysaccharide containing intine is degraded (Shivanna and Johri, 1985). Zones 1-3 of the pecan pollen wall remained intact even after all other cellular components had degraded and, thus, are considered to be exine. The exine is subdivided into two components, sexine (Zones 1 and 2) and nexine (Zone 3), and is of the tectate type with the tectum (Zone 1) forming a roof covering the bacula (Zone 2). The electron-translucent spaces in Zone 2 are called lumina. The stratification of the pecan pollen wall was like that recently described for Juglans (Calzoni et al., 1990).

In summary, external morphological characteristics of catkin development can be used to gauge maturation of reproductive cells in the anthers of pecan. Predominating periods of reproductive cell development were the same for Stage III-V catkins in 'Desirable' and 'Stuart', a protandrous and a protogynous cultivar, respectively. Catkins in Stage II of development should

Table 3. Comparison of the most distinctive aspects of anther histogenesis and reproductive cell development associated with each catkin stage.

\begin{tabular}{|c|c|c|c|c|c|c|}
\hline \multirow[b]{2}{*}{ Cultivar } & \multirow[b]{2}{*}{$\begin{array}{c}\text { Anther } \\
\text { maturation }\end{array}$} & \multicolumn{5}{|c|}{$\begin{array}{l}\text { Catkin stage } \\
\text { (characteristic) }\end{array}$} \\
\hline & & $\begin{array}{c}\text { I } \\
\text { (only bracts } \\
\text { visible) }\end{array}$ & $\begin{array}{c}\text { II } \\
\text { (bracts and } \\
\text { bracteoles } \\
\text { visible) } \\
\end{array}$ & $\begin{array}{c}\text { III } \\
\left(45^{\circ} \text { angle }\right. \\
\text { between bract } \\
\text { and rachis }) \\
\end{array}$ & $\begin{array}{c}\text { IV } \\
\text { (anthers } \\
\text { visible) }\end{array}$ & $\begin{array}{c}\mathrm{V} \\
\text { (anthers } \\
\text { yellowish) } \\
\end{array}$ \\
\hline \multirow[t]{3}{*}{ Desirable } & Histogenesis ${ }^{z}$ & Tapetum & $\begin{array}{l}\text { Endothecium } \\
4 \text { locules }\end{array}$ & $\begin{array}{l}\text { Endothecium } \\
4 \text { locules }\end{array}$ & $\begin{array}{l}\text { Endothecium } \\
2 \text { locules }\end{array}$ & $\begin{array}{l}\text { Endothecium } \\
2 \text { locules }\end{array}$ \\
\hline & Reproductive & Before free & \multicolumn{4}{|c|}{ Period } \\
\hline & cell & microspore & $1 \& 2$ & 4 & $5 \& 6$ & 7 \\
\hline \multirow[t]{3}{*}{ Stuart } & Histogenesis & Locule & Tapetum & $\begin{array}{l}\text { Endothecium } \\
4 \text { locules }\end{array}$ & $\begin{array}{l}\text { Endothecium } \\
2 \text { locules }\end{array}$ & $\begin{array}{l}\text { Endothecium } \\
2 \text { locules }\end{array}$ \\
\hline & \multirow{2}{*}{$\begin{array}{l}\text { Reproductive } \\
\text { cell }\end{array}$} & \multirow{2}{*}{$\begin{array}{l}\text { Before free } \\
\text { microspore }\end{array}$} & \multirow{2}{*}{$\begin{array}{l}\text { Before free } \\
\text { microspore }\end{array}$} & \multicolumn{3}{|c|}{ Period } \\
\hline & & & & 4 & $5 \& 6$ & 7 \\
\hline
\end{tabular}

${ }^{2}$ Yates and Sparks, 1991. 
be selected to initiate haploid anther culture with free microspore prior to nuclear enlargement. However, reproductive cell development should be verified by cytological analyses, as $15 \%$ of 'Desirable' catkins and $90 \%$ of 'Stuart' Stage II catkins were too immature to have free microspore. Further studies are required to identify other catkins characteristics useful in more accurate predictions of reproductive cell development of Stage II catkins.

\section{Literature Cited}

Belling, J. 1926. The iron-acetocarmine method of fixing and staining chromosomes. Biol. Bul. 50:160-162.

Brewbaker, J.L. 1957. Pollen cytology and self-incompatibility systems in plants. J. Her. 48:271-277.

Calzoni, G.L., A. Speranza, R. Caramiello, G. Piccone, and P. Zannini. 1990. Wall ultrastructure and biochemical features of the Juglans regia L. and Juglans nigra L. male gametophyte. Sexual Plant Reproduction 3:139-146.

Cope, M. and I.E. Yates. 1987. Relationship between floret differentiation and microsporogenesis in pecan. HortScience 22:724. (Abstr.)

Davis, J.T. and D. Sparks. 1971. Assimilation of ${ }^{14} \mathrm{CO}_{2}$ by catkins of Carya illinoensis and apparent translocation to the pollen. Amer. J. Bot. 58:932-938.

Fisher, D.B. 1968. Protein staining of ribboned epon sections for light microscopy. Histochemie 16:92-96.

Haulik, T.K. 1985. Pomological, morphological and anatomical study of the pecan [Carya illinoensis (Wang.) K. Koch]. PhD Diss., Univ. of Pretoria, Pretoria, S. Afr.

Haulik, T.K. and L.C. Holtzhausen. 1988. Anatomy of staminate flower ontogeny of the pecan as determined by scanning electron microscopy. S. Afr. J. Plant Soil 5:205-208.

Heslop-Harrison, J. 1972. Sexuality of angiosperms, p. 133-289. In: F.C. Steward (ed.). Plant physiology-A treatise. WC: Physiology of development: From seeds to sexuality. Academic, New York.

Johansen, D.A. 1940. Plant microtechnique. McGraw-Hill, New York.

Knox, R.B. 1984. The pollen grain, p. 197-271. In: B.M. Johri (ed.). Embryology of angiosperms. Springer-Verlag, New York.

Knox, R.B., E.G. Williams, and C. Dumas. 1986. Pollen, pistil, and reproductive function in crop plants, p. 9-79. In: J. Janick (ed.). Plant breeding reviews. vol. 4. Avi Publishing, Westport, Corm.

Maximos, S.E., A.Z. Bondok, M.A. Salama, S.M. Habib, and N.F. Youssuf. 1984. Histological studies on distillate and staminate floral bud's differentiation of "Curtis" pecan. Ann. Agr. Sci., Faculty Agr., Ain-Shams Univ., Cairo 29: 1015-1025.

Pearse, A.G.E. 1961. Histochemistry-Theoretical and applied. Little, Brown, Boston.

Sangwan, R.S. and B.S. Sangwan-Norreel. 1987. Ultrastructural cytology of plastids in pollen grains of certain androgenic and nonandrogenic plants. Protoplasm 138: 11-22.

Shivanna, K.R. and B.M. Johri. 1985. The angiosperm pollen: Structure and function. Wiley Eastern Limited, New Delhi.

Skvarla, J.J. and J.R. Rowley. 1970. The pollen wall of Canna and its similarity to the germinal apertures of other pollen. Amer. J. Bot. 57:519-529.

Sparks, D. 1987. Pollen shedding and stigma receptivity in pecan-A review. Annu. Rpt. Northern Nut Growers Assn. 78:127-140.

Sparks, D. and G.D. Madden. 1985. Distillate flower and fruit abortion in pecan as a function of cultivar, time, and pollination. J. Amer. Soc. Hort. Sci. 110:219-223.

Spurr, A.R. 1969. A low-viscosity epoxy resin embedding medium for electron microscopy. J. Ultrastructure Res. 26:31-43.

Sunderland, N. and J.M. Dunwell. 1977. Anther and pollen culture, p. 223-265. In: H.E. Street (cd.). Plant tissue and cell culture. Univ. of Calif. Press, Berkeley.

Wetzstein, H.Y. and D. Sparks. 1984. The morphology of staminate flower differentiation in pecan. J. Amer. Soc. Hort. Sci. 109:245252.

Wetzstein, H.Y. and D. Sparks. 1985. Structure and in vitro germination of the pollen of pecan. J. Amer. Soc. Hort. Sci. 110:778781 .

Willemse, M.T.M. and S.A. Reznickova. 1980. Formation of pollen in the anther of Lilium. I. Development of the pollen wall. Acta Bot. Neerl. 29:127-140.

Woodroof, J.G. 1930. Studies of the staminate inflorescence and pollen of Hicoria pecan. J. Agr. Res. 40:1059-1104.

Yates, I.E. and D. Sparks. 1989. Hydration and temperature influence in vitro germination of pecan pollen. J. Amer. Soc. Hort. Sci. 114:599605.

Yates, I.E. and D. Sparks. 1990. Three-year-old pecan pollen retains fertility. J. Amer. Soc. Hort. Sci. 115:359-363.

Yates, I.E. and D. Sparks. 1992. External morphological characteristics for histogenesis in pecan anthers. J. Amer. Soc. Hort. Sci. 117(1):181-189.

Yates, I.E., B. Wood, and J.L. Giles. 1986. Relationship of catkin and pollen development in pecan. HortScience 21:936. (Abstr.) 